\title{
Edge and land use effects on dung beetles (Coleoptera: Scarabaeidae: Scarabaeinae) in Brazilian cerrado vegetation
}

\author{
Felipe Martello 1 ( \\ Pavel Dodonov ${ }^{3} \cdot$ Milton Cezar Ribeiro $^{1}$
}

Received: 17 February 2016 / Accepted: 5 October 2016 / Published online: 12 November 2016

(C) Springer International Publishing Switzerland 2016

\begin{abstract}
The Edge Influence is one of the most pervasive effects of habitat fragmentation, as many forest remnants in anthropogenic landscapes are within $100 \mathrm{~m}$ of edges. Forest remnants may also affect the surrounding anthropogenic matrix, possibly resulting in a matrix-edgeremnant diversity gradient for some species groups. We sampled dung beetles in 15 agricultural landscapes using pitfall traps placed along transects in matrix-edge-remnant gradients. The remnants were a native savanna-like vegetation, the cerrado, and the matrix was composed of three human-dominated environments (sugarcane, eucalyptus, pasture). More species were observed in cerrado remnants than in adjacent land uses. Dung beetles were also more abundant in the cerrado than in the landscape matrix of sugarcane and eucalypt, but not of pasture. Dung beetles were severely affected by anthropogenic land uses, and notwithstanding their high abundance in some land uses such as pasture, the species richness in these areas tended to be smaller than in the cerrado remnants. We also found that the influence of the edge was evident only for abundance,
\end{abstract}

Electronic supplementary material The online version of this article (doi:10.1007/s10841-016-9928-0) contains supplementary material, which is available to authorized users.

Felipe Martello

felipemartello@gmail.com

1 Spatial Ecology and Conservation Lab (LEEC), Ecology Department, São Paulo State University, UNESP, Avenida 24 A, 1515 Bela Vista, Rio Claro, SP, Brazil

2 Post Graduation Program in Ecology, National Institute of Amazon Research - INPA, Av. André Araújo, 2936 Manaus, AM, Brazil

3 Applied Ecology and Conservation Lab, Biological Science Department, State University of Santa Cruz, UESC, Rodovia Ilhéus-Itabuna, km 16, 45662-000 Ilhéus, BA, Brazil particularly in landscapes with a pasture matrix. However, this land use disrupts the species composition of communities, indicating that communities located in cerrado and pasture have a distinct species composition, and that both communities are affected by edge distance. Thus, anthropogenic land uses may severely affect dung beetles, and this impact can extend to communities located in cerrado remnants as well as to those in matrices, with possible consequences for ecological processes such as decomposition and nutrient cycling.

Keywords Brazilian savanna - Sugarcane - Pasture · Eucalyptus · Akaike's Information Criterion

\section{Introduction}

Habitat fragmentation is one of the major threats to biodiversity (Butchart et al. 2010). Among its most pervasive effects are those related to changes in microhabitat conditions at the interface between natural and anthropogenic land uses, a phenomenon referred to as edge influence (Fahrig 2003). Over $20 \%$ of the remaining forest vegetation worldwide is located within $100 \mathrm{~m}$ of an edge (Haddad et al. 2015) and therefore may be subject to severe edge influence (Harper et al. 2005). This situation may be even worse in some tropical forests-for example, nearly $50 \%$ of the Brazilian Atlantic forest area is $100 \mathrm{~m}$ or less from the edge of the forest (Ribeiro et al. 2009). Vegetation edges in human-dominated landscapes are characterized by changes in species composition (Foggo et al. 2001; Harper et al. 2005), with a greater abundance of generalist and invasive species than in undisturbed areas (Laurance et al. 2002). Soil insects, which are responsible for important ecological processes such 
as decomposition and nutrient cycling (Whitford 1996; Brussaard et al. 1997), are among the groups affected by edges in both tropical and temperate regions (Meyer et al. 2009; Delgado et al. 2013a, b; Barrera et al. 2015). Still, notwithstanding the large number of studies demonstrating the influence of edges on different organisms, many others have failed to detect edge-related gradients, and there is still no consensus on how edges affect some organisms (Ries et al. 2004).

Edge influence may depend on the type of matrix surrounding the forest fragments (Delgado et al. 2007; Pohlman et al. 2007; Kowal and Cartar 2012). Edge influence is expected to be greater when the fragment and the adjacent land use are more dissimilar in terms of vegetation structure, ecological processes and/or microclimate (Ries et al. 2004; Harper et al. 2005). For example, higher-contrast edges exerted a stronger edge influence than lower-contrast edges on air moisture in the Brazilian cerrado (Dodonov et al. 2013), on dung beetles in Argentinian Atlantic Forest (Peyras et al. 2013), and on flying insects in New Zealand (Campbell et al. 2011). Thus, when edge contrast is lower, the microclimate and vegetation at the edge may be similar to the reference conditions, and an organism may occur with equal abundance at the edge and in the fragment's interior, even if it is more or less abundant in the matrix. The same applies to the effects exerted by the vegetation remnant on the surrounding matrix. Conversely, some studies failed to detect a relationship between edge contrast and vegetation structure (Dodonov et al. 2013) or plant litter biomass (Dodonov et al. 2016) in the cerrado, showing that this relationship is not universal.

Furthermore, a number of organisms, particularly the more generalist ones, may use the matrix habitat as well as the native vegetation remnants. For example, matrix habitats may be important to, or at least usable as complementary habitat (Ries et al. 2004) by, non-volant small mammals (Martin et al. 2012; Cooney et al. 2015), by birds (Hansbauer et al. 2009) and by several arthropod species (Borges and Brown 2001; Dennis et al. 2006). Even organisms that survive better in forested environments may use the matrix, albeit with lower abundances than in the vegetation fragments. The abundance of different organisms and the number of species of a given group in the fragments and in the matrix will depend on the resources available in each environment and will therefore vary between matrix types (Ries et al. 2004; Driscoll et al. 2013). For example, in comparison to a monoculture matrix, an agroforestry matrix may offer a larger quantity of resources and will probably harbor a greater number of species occurring in greater abundances. Both the edge contrast and matrix suitability may affect the existence and shape of edge-related gradients in agricultural landscapes, with edge contrast affecting the gradient's degree of conspicuousness, and the matrix quality affecting the difference in abundance between the forest and the matrix.

To aid in understanding the effects of different matrices on edge influence and the distribution of organisms, we addressed the variation in richness and abundance of an important group of soil insects-the dung beetles (Coleoptera: Scarabaeinae)-in Brazilian cerrado fragments and the surrounding human-dominated environments in Southeast Brazil. We focused on this group of organisms because they are highly diverse in tropical regions and provide several ecosystem functions such as decomposition of organic matter in nutrient cycling, improvement of physical and chemical properties of soil, parasite suppression and secondary seed dispersion (Nichols et al. 2007, 2008; Campos and Hernández 2013). In addition, due to their association with vegetation structure (Hanski and Camberfort 1991a, b; Nichols et al. 2007; Gardner et al. 2010; Almeida et al. 2011), they are sensitive to habitat alteration and are one of the first organisms to be affected by anthropogenic disturbance (Larsen and Forsyth 2005). For that reason, and because dung beetles are easily sampled and have a wellknown ecology and taxonomy, these insects are widely used for biodiversity monitoring, especially in agricultural or anthropogenic environments (Audino et al. 2014; Figueiras et al. 2015).

Coprophagy, the consumption of faeces, is the fundamental feature of the biology of Scarabaeinae and determines characteristics of behavior, morphology, development and distribution (Halffter and Matthews 1996). Dung beetles use faeces for feeding or oviposition (Hanski and Cambefort 1991a, b), and resource partitioning, through different dung-manipulation strategies, allows the coexistence of many species (Hanski and Cambefort 1991a, b). Regarding dung-manipulation strategies, this group is divided into three guilds: telecoprids (rollers—adults group an amount of faeces into a ball and roll it some distance from the point of origin); paracoprids (tunnelers-adults dig tunnels in the soil under the faeces); and endocoprids (dwellers-adults and larvae feed within the fresh faecal deposits). These dung-manipulation strategies feature much variation regarding the depth, speed and amount of faeces buried (Doube 1990). The several ecosystem functions provided by dung beetles are more dependent on these functional properties and combinations of species than on species richness alone (Slade et al. 2007), and this functional richness may decrease as a result of habitat loss and fragmentation (Barragán et al. 2011).

We assessed how the abundance, richness and composition of dung beetles as a whole and of the different dung-manipulation strategies (telecoprids, paracoprids and endocoprids) in Brazilian cerrado (a savanna-like vegetation) fragments are affected by different land uses: pasture; sugarcane (Saccharum officinarum) plantations; 
and eucalypt (Eucalyptus spp.) plantations. We expected species richness, for dung beetles as a whole and for each guild, to be greater in the cerrado than in the adjacent matrices due to increased resource variability. We expected total dung beetle abundance to be greater in the pasture than in the cerrado due to resource availability, but to be lower in the other matrices compared to the cerrado. This hypothesis also reflects the pattern expected for paracoprids, as this guild is often the most abundant, and its behavior of storing faeces in underground tunnels enables these species to survive in drier environments. Finally, we expected to observe edge-related gradients in the low-contrast matrix, namely eucalypt (due to its forest-like phytophysionomy) and pasture (low management), because these environments present less difference between the cerrado and the adjacent matrix, allowing species that are characteristic of both environments to use the edge zone. In the high-contrast matrix, namely sugarcane, we expected a discontinuous pattern, as many species would be restricted to either the cerrado or the matrix (Fig. 1).

\section{Methods}

\section{Study area}

We performed this study in 15 agricultural landscapes composed of fragments of cerrado sensu stricto vegetation surrounded by different land uses. The landscapes are located in the Corumbataí river basin, São Paulo State, Southeast Brazil, between latitudes $22^{\circ} 04^{\prime} 46^{\prime \prime} \mathrm{S}$ and $22^{\circ} 41^{\prime} 28^{\prime \prime} \mathrm{S}$ and longitudes $47^{\circ} 26^{\prime} 23^{\prime \prime} \mathrm{W}$ and $47^{\circ} 56^{\prime} 15^{\prime \prime} \mathrm{W}$ (Fig. 2). The cerrado is characterized by a savanna woodland with a discontinuous canopy layer and tree heights between 5 and $8 \mathrm{~m}$; heliophilous grasses, sedges, herbaceous species and subshrubs occupy its ground layer (Coutinho 1978; Ribeiro and Walter 2008). Three of the studied fragments were

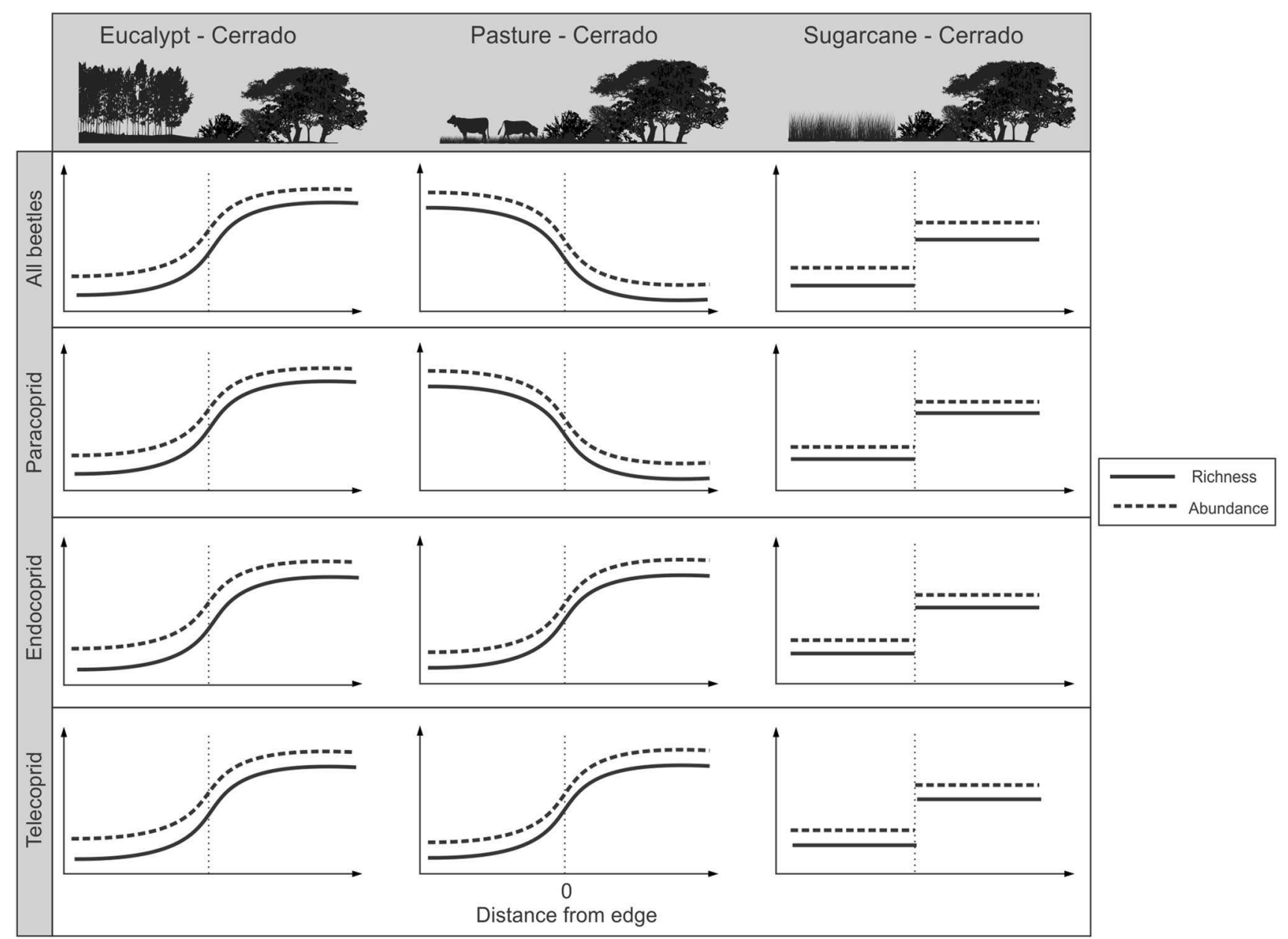

Fig. 1 Schematic representation of expected responses of dung beetle abundance and species richness, total and per guild, to distance from edge for three different land uses (pasture, eucalypt and sug- arcane). Two horizontal lines represent the categorical fragmentmatrix model and a non-linear curve represents the gradient model 


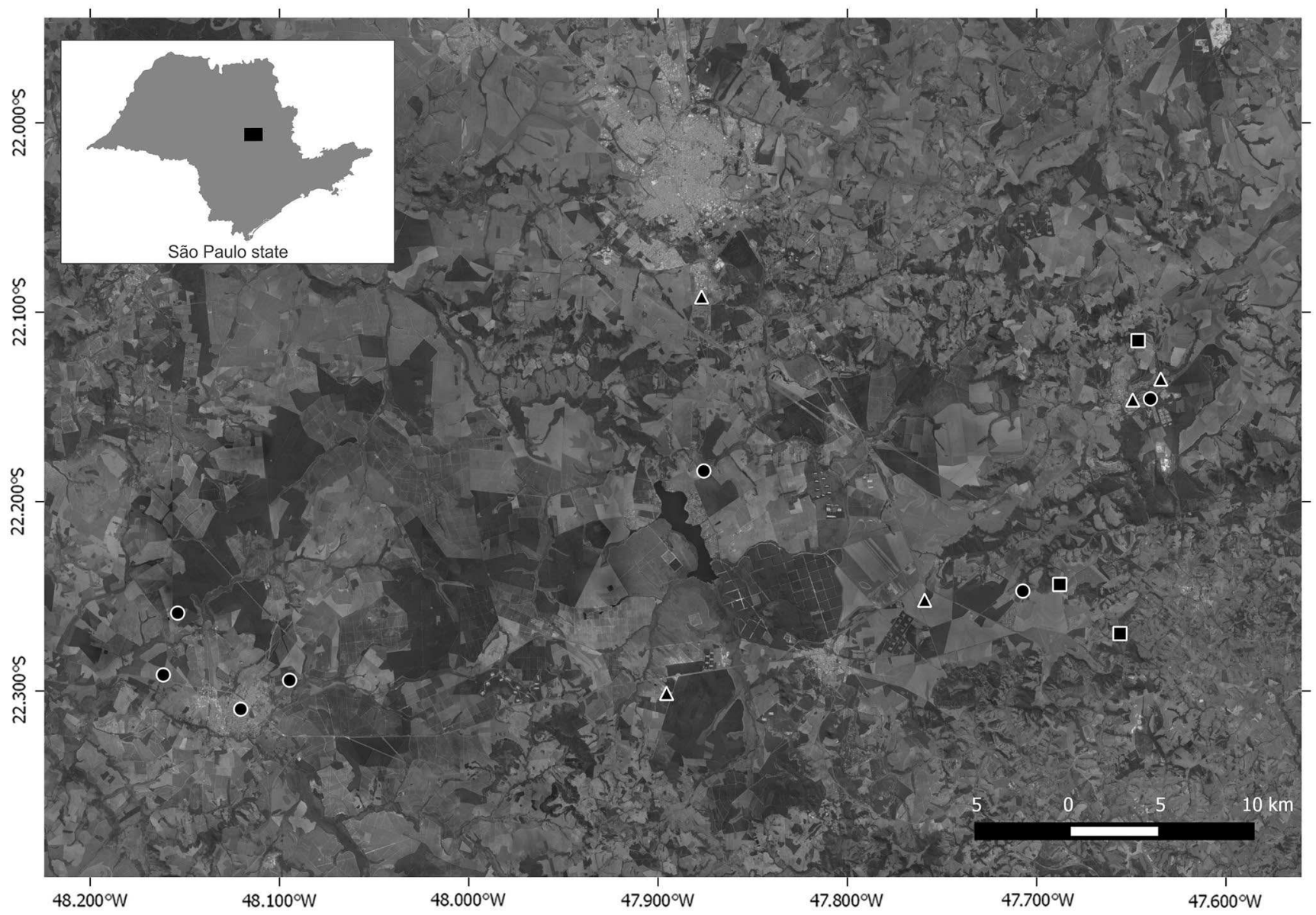

Fig. 2 Satellite image of the location of the study landscapes. The small map indicates the location of the image (black rectangle) within the State of São Paulo (dark grey), Brazil (light grey). Polygons rep-

surrounded by pastures, five by eucalypt plantations and seven by sugarcane plantations (Table 1). Pastures were large open areas without intensive management (application of herbicides or pesticides) and with low stocking rates (between 0.3 and 1.14 cattle per hectare) (Sparovek et al. 2011). This region is characterized by a subtropical drywinter climate (Valente 2001) with average yearly precipitation of about $1,400 \mathrm{~mm}, 80 \%$ of which is concentrated between October and February (Zavatini and Cano 1993).

\section{Dung beetle sampling and identification}

In each of the study fragments, we established two transects placed $50 \mathrm{~m}$ apart and perpendicular to the fragment's edge. Each transect contained eight pitfall traps, four in the matrix and four in the fragment, with $25 \mathrm{~m}$ between adjacent traps. Although the distance between traps was smaller than recommended for independent samples (Larsen and Forsyth 2005; Silva and Hernández 2015), a wider spacing could have precluded the resent the type of matrix that composed the cerrado boundaries: squares represent pasture, triangles represent eucalyptus plantations, and circles represents sugarcane plantations

detection of edge-related gradients. The traps closest to the fragment - matrix boundary within each transect were positioned in both the fragment and the matrix at $12.5 \mathrm{~m}$ from the boundary. The traps were composed of a 1-L cylindrical receptacle holding $250 \mathrm{~mL}$ of water with $2 \%$ detergent, saturated with sodium chloride to minimize decomposition. At the center of the receptacle, we placed human faeces as bait in a $50-\mathrm{mL}$ plastic cup suspended from a wire, and we covered the trap with a tilted Styrofoam disk for protection against rain and desiccation of the bait (Hernandez and Vaz-de-Mello 2009). As only human faeces were used as an attractant, only coprophagous Scarabaeinae were sampled. The traps were exposed for $48 \mathrm{~h}$, after which their contents were passed through a fine mesh and deposited in plastic bags with $70 \%$ alcohol for subsequent processing and species identification in the lab. Each transect was sampled three times between December 2011, January and February 2012, the period of highest abundance of this group in southern Brazil (Hernández and Vaz-de-Mello 2009). 
Table 1 Characteristics of the study areas of dung beetle communities, including the dominant matrix, its municipality (all in São Paulo State, Southeastern Brazil), coordinates of each landscape (decimal degrees) and total number of species found in each study site and in the corresponding fragment and matrix

\begin{tabular}{|c|c|c|c|c|c|c|c|}
\hline \multirow[t]{2}{*}{ Landscape } & \multirow[t]{2}{*}{ Matrix } & \multirow[t]{2}{*}{ Municipality } & \multicolumn{2}{|c|}{ Coordinates } & \multicolumn{3}{|c|}{ Number of species } \\
\hline & & & Latitude & Longitude & Total & Cerrado & Matrix \\
\hline P1 & Pasture & Analândia & -22.115 & -47.646 & 17 & 14 & 13 \\
\hline $\mathrm{P} 2$ & Pasture & Corumbataí & -22.270 & -47.656 & 35 & 34 & 21 \\
\hline P3 & Pasture & Analândia & -22.244 & -47.688 & 20 & 16 & 14 \\
\hline E1 & Eucalypt & Itirapina & -22.252 & -47.759 & 23 & 14 & 19 \\
\hline E2 & Eucalypt & Brotas & -22.301 & -47.896 & 23 & 19 & 17 \\
\hline E3 & Eucalypt & São Carlos & -22.092 & -47.877 & 23 & 12 & 16 \\
\hline E4 & Eucalypt & Analândia & -22.146 & -47.649 & 30 & 19 & 17 \\
\hline E5 & Eucalypt & Analândia & -22.135 & -47.634 & 25 & 19 & 15 \\
\hline $\mathrm{S} 1$ & Sugarcane & Itirapina & -22.247 & -47.707 & 21 & 16 & 7 \\
\hline S2 & Sugarcane & Itirapina & -22.184 & -47.876 & 28 & 17 & 25 \\
\hline S3 & Sugarcane & Brotas & -22.259 & -48.154 & 25 & 21 & 14 \\
\hline S4 & Sugarcane & Brotas & -22.310 & -48.120 & 26 & 18 & 15 \\
\hline S5 & Sugarcane & Brotas & -22.291 & -48.161 & 35 & 27 & 16 \\
\hline S6 & Sugarcane & Brotas & -22.294 & -48.095 & 34 & 22 & 22 \\
\hline S7 & Sugarcane & Analândia & -22.146 & -47.640 & 18 & 15 & 9 \\
\hline
\end{tabular}

Landscapes P1-P3 are occupied by a pasture matrix, E1-E5 by eucalypt and S1-S7 by sugarcane
Dung beetles were then identified to the most detailed taxonomic level possible, and information on their guilds was obtained from the literature (Halffter and Matthew 1996; Doube 1990; Vulinec 2002; Alarcón et al. 2009; Liberal et al. 2011; Beiroz 2012).

\section{Data analysis}

For the analyses, we pooled the data for each distance, along each transect, thus combining the data from the three campaigns and the two transects corresponding to each distance. We then used the landscapes with each dominant land use (pasture, eucalypt or sugarcane) as replicates, thus having 3-8 replicates at each distance for each land use. We used total abundance and richness and the abundance and richness of each guild as response variables.

We analyzed the relationship of each response variable with positions along the transect by adjusting three competitive models: a null model, a categorical fragment-matrix model, and a continuous interior-edge-matrix model, which we called the gradient model. The adjustments were made as generalized linear or additive mixed models with a Poisson distribution. The null model assumes that the response variable is homogeneous along the transect and is not affected by the position along the transect nor by the environment. The fragment-matrix model assumes that the response variables do not vary with distance into the fragment nor into the matrix, but may vary between these two environments (e.g. total abundance in sugarcane landscapes in Fig. 1). The gradient model assumes that the response variables are related to their position along the transect (from $-85 \mathrm{~m}$ into matrix to $85 \mathrm{~m}$ into the interior of the cerrado, where zero is the edge transitional zone), without explicitly differentiating between fragment and matrix (e.g. total abundance in eucalypt and pasture landscapes in Fig. 1). Thus, the fragment-matrix model considers only differences between the two environments (habitat and matrix), whereas the gradient model is able to account for edge influence and for continuous variation along the transect. The null model was represented by a linear interceptonly model; the fragment-matrix model, by a generalized linear model with the two habitat types modeled as categorical variables; and the gradient model, by an additive model with a smoothing function for distance along the transects. In all analyses, we included the sampled landscape as a random factor and calculated the (Laplace approximate) maximum likelihood. The optimal amount of smoothing in the gradient model was defined by means of a cross-validation procedure (Zuur et al. 2009).

Using Akaike's Information Criterion corrected for small sample size (AICc), we calculated the values for the three models as well as for the difference in the AICc of each model relative to the model with the smallest AIC value $(\triangle \mathrm{AICc})$. We selected the model with the smallest AICc when the $\triangle \mathrm{AICc}$ of other models was $>2.0$, as models with a $\triangle \mathrm{AIC}$ of 2.0 or less may be considered as having substantial support (Burnham and Anderson 2002). Although there are several criticisms of the use of an arbitrary cutoff to determine which model is best (Burnham and Anderson 2014; Murtaugh 2014; Valpine 2014), we chose to define an $a$ priori cutoff because of the large number of response variables, which would otherwise have made a more thorough assessment of the support for each model too subjective. When two or more 
models had small $\triangle \mathrm{AICc}$ values, we selected the simplest model. When both the gradient and the fragment-matrix models had $\triangle \mathrm{AICc}$ of 2.0 or less, we selected the simpler fragment-matrix model because it assumes that there are differences between the two areas but no edge influence. When the simplest null model was among the models with a $\triangle \mathrm{AICc}$ of 2.0 or less, we considered it as the best model because it assumes neither edge influence nor differences between the two areas.

When either the fragment-matrix or the gradient model was selected, we also noted whether species richness was greater in the fragment or the matrix. Thus, there were five possible outcomes for each response variable at each landscape type: no response (null model); greater abundance in the matrix, with no gradient; greater abundance in the fragment, with no gradient; greater abundance in the matrix, with a gradient indicating edge influence; or greater abundance in the fragment, with a gradient indicating edge influence.

We also performed a non-metric multidimensional scaling ordination (NMDS) of all landscapes, using Bray-Curtis distance, to describe and interpret the patterns of community composition along the edge distance.

All analyses were performed in R 3.2.4 (R Core Team 2015). The null and fragment - matrix model were adjusted with the glmer function of the lme4 package (Bates et al. 2015), whereas the gradient models were adjusted with the gamm4 package (Wood and Sheipl 2014), based on the mgcv (Wood 2011) package. The AICc values were obtained with the MuMIn package (Barton 2015). The NMDS ordination was performed with the vegan package (Oksanen et al. 2013).

\section{Results}

In the 15 study areas, we sampled a total of 8398 individuals, belonging to 57 species and 21 genera. We observed between 3 and 165 (mean of $25.1 \pm 40.1$ SD) individuals per pitfall in the different matrices and between 13 and 118 (mean of $44.9 \pm 26.9$ ) individuals per pitfall in the fragments (Fig. 3). The mean number of species per

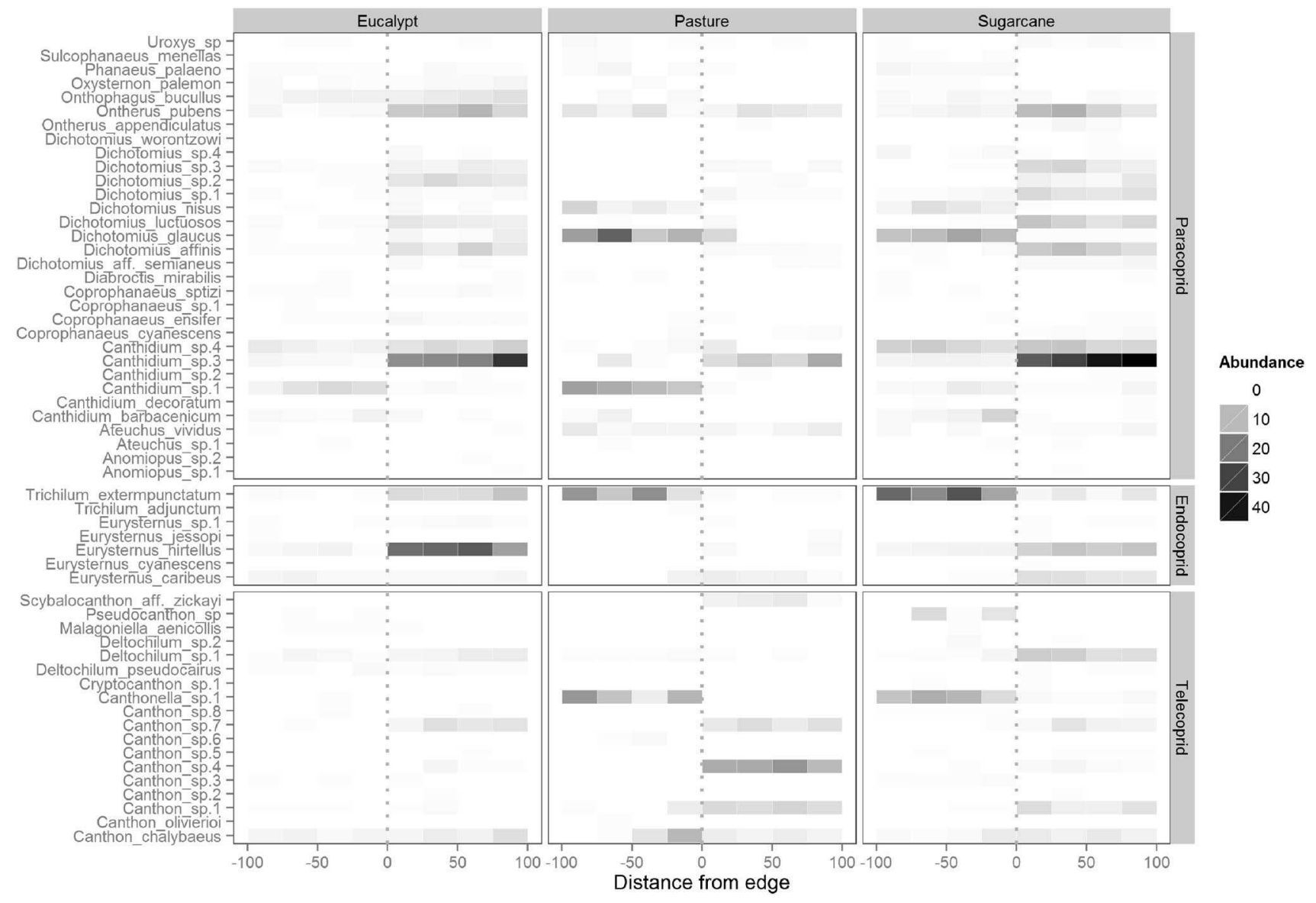

Fig. 3 Abundance of dung beetle species, per resource allocation guild, sampled in landscapes composed of the Brazilian savanna, cerrado (positive values of distance from edge), and three different land uses (negative values of distance from edge). Vertical dotted lines represent edges between cerrado and its adjacent matrix 
pitfall ranged from 2.3 to 10.9 (mean of $5.5 \pm 2.4$ ) species in the matrix and from 5 to 15.1 (mean of $8.9 \pm 2.8$ ) in the cerrado. The paracoprid guild was the richest in species (32 species), followed by the telecoprid (18 species) and the endoprid (seven species), and the abundance of most species differed between the matrix and the remnants (Fig. 3). The most abundant guild in both cerrado and matrix (regardless of the type of land use) was the paracoprid, with 3496 individuals in cerrado (mean of $10.53 \pm 12.56$ per pitfall) and 1578 individuals in different matrices (mean of $5.42 \pm 9.65$ per pitfall). The endocoprid guild had 986 individuals sampled in the cerrado (mean of $2.97 \pm 7.09$ per pitfall) and 807 individuals in different matrices (mean of $2.77 \pm 12.61$ per pitfall). The telecoprid was the least abundant guild, with 907 individuals sampled in the cerrado (mean of $2.73 \pm 3.67$ per pitfall) and 624 individuals in different matrices (mean of $2.14 \pm 7.01$ per pitfall).
The patterns of total abundance and richness varied among land uses, and their response to edge distance always followed the same pattern demonstrated by the paracoprid guild. Total and paracoprid abundances decreased linearly from the matrix into the cerrado in the pasture landscapes (gradient model), but they were greater in the cerrado than in the matrices of the eucalypt and sugarcane landscapes, with no edge influence detected (Fig. 4). The numbers of total and paracoprid species did not vary between matrix and cerrado in the pasture landscapes and were smaller in the matrices of the other landscapes (Fig. 5). The abundance of endocoprids was greater in the matrices than in the cerrado in the pasture and sugarcane landscapes, but smaller in the matrices of the eucalypt landscapes, with no detectable edge influence in any landscape (habitat-matrix model) (Fig. 4). The richness of this guild was greater in the matrices than in the cerrado in the eucalypt and
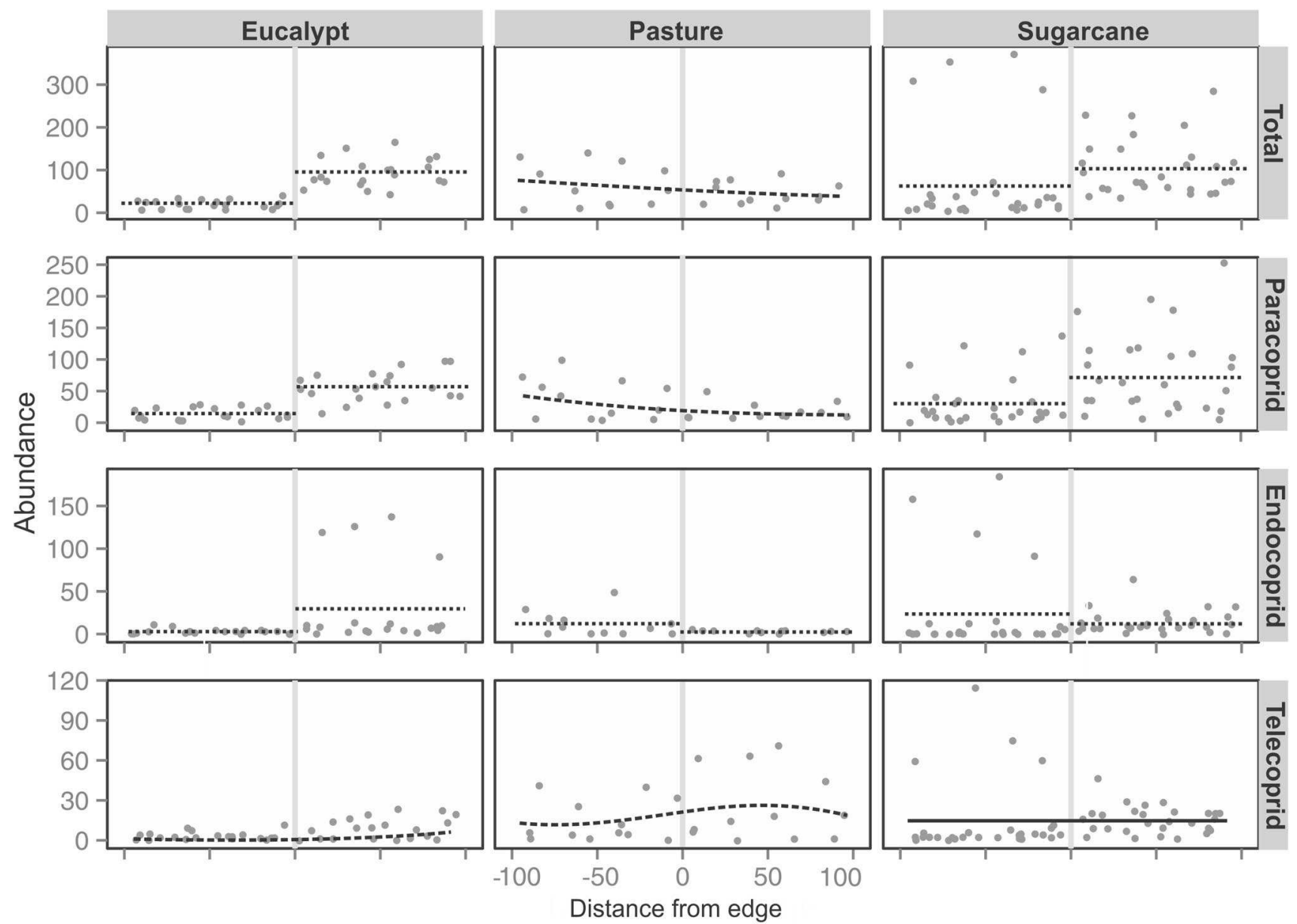

Fig. 4 Abundance of dung beetle resource allocation guilds sampled in landscapes composed by the Brazilian savanna, cerrado (positive values of distance from edge), and three different land uses (negative values of distance from edge). Vertical lines at zero value on $\mathrm{x}$-axes represent the edge between the two environments composing the landscape. Black lines represent the selected model, expressing the response of dung beetles to edge distance: dashed line represents the gradient model, two dotted lines represent the fragment-matrix model, and continuous lines represent the null model 

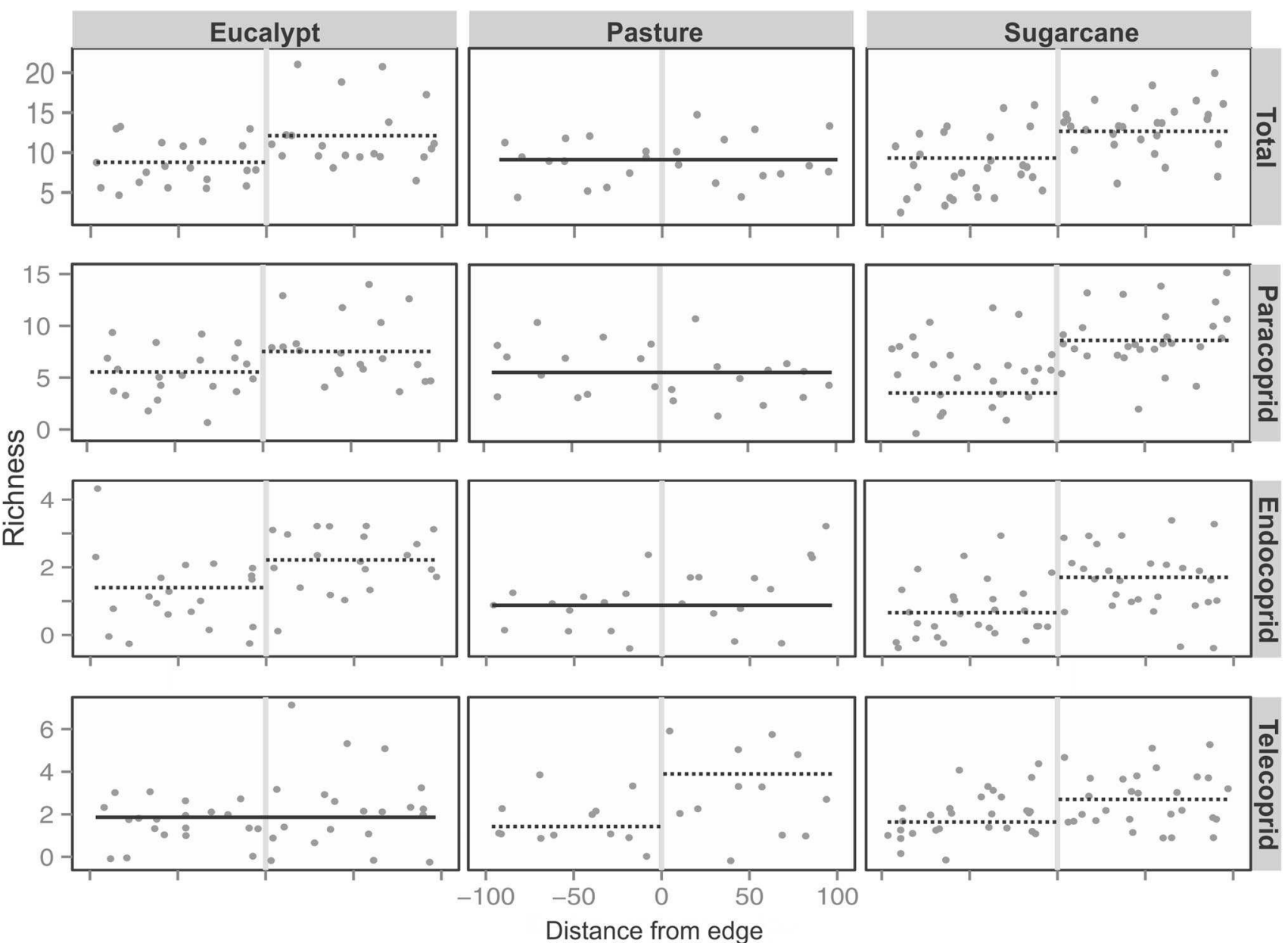

Fig. 5 Richness of dung beetle resource allocation guilds sampled in landscapes composed of the Brazilian savanna, cerrado (positive values of distance from edge), and three different land uses (negative values of distance from edge). Vertical lines at zero value on $\mathrm{x}$-axes represent the edge between the two environments composing the landscape. Black lines represent the selected model, expressing the response of dung beetles to edge distance: two dotted lines represent the fragment-matrix model, and continuous lines represent the null model

\section{Discussion}

Our results showed great variation in the abundance and richness of dung beetles between the cerrado fragments and the adjacent matrix. This variation was observed for all beetles, for guilds and for some species. Our expectations regarding the number of dung beetle species were mostly confirmed, which was generally larger in the cerrado fragments than in the adjacent matrix. This indicates that, even though many dung beetle species are able to survive in the matrix, the natural vegetation offers a greater variety of resources and habitats for their survival. Regarding beetle abundances, our expectations were mostly confirmed: dung beetles were frequently more abundant in the pasture than in the adjacent cerrado, but less abundant in the other anthropogenic land uses. Dung beetle abundance depends on the specific land 


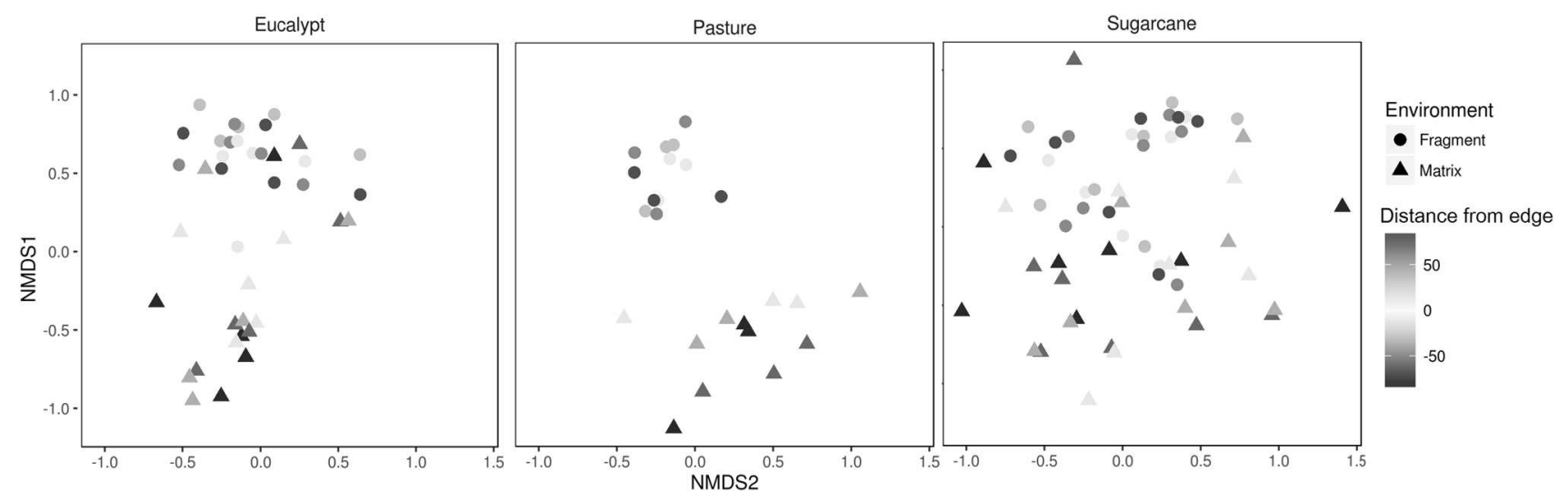

Fig. 6 Non-metric multidimensional scaling ordination (NMDS) of dung beetles sampled in transects in landscapes composed of the Brazilian savanna, cerrado (fragment), and three different land uses (matrix)

use being considered, and simply classifying land uses as either natural or anthropogenic does not provide an adequate description of the impacts on the community.

Scarabeinae differ in their preference regarding physical and chemical characteristics of faeces (Gittings and Giller 1998) and have been shown to discriminate differences in nutritional value (Verdú and Galante 2004), dung shape (Gordon and Cartwright 1974), water and/ or fibre content (Verdú and Galante 2004) and dung size (Peck and Howden 1984). Thus, increasing the diversity of faeces (especially from large mammals) promotes an increase in the diversity of dung beetles (Nichols et al. 2009). Although pastures may have a greater abundance of resources than other land uses, these resources usually come from a single provider-cattle. The dominance of cattle in this matrix suggests high competition between species that prefer this resource, resulting in the dominance of only a few species (Louzada and Silva 2009; Almeida et al. 2011). Moreover, high cattle density causes soil compaction, which has negative impacts on dung beetle diversity (Almeida et al. 2011). In this study, we detected an increase in the total abundance of dung beetles in the pasture matrix, as would be expected from the increase in resource quantity. Contrarily to our expectations, the richness in the pasture landscapes did not change between the matrix and the adjacent cerrado. However, this outcome does not mean an absence of change between dung communities located in these two habitats, since the NMDS ordination showed that the composition of communities located in these adjacent habitats were different, indicating that the pasture modifies the community composition of dung beetles to a greater degree than the adjacent cerrado. Although most dung beetles in tropical savanna are not host specialists (Spector and Ayzama 2003), the characteristics of the habitat wherein the dung is located, as well as the competition between species, can play a key role in determining the community composition (Roslin and Vijanen 2011).

In highly modified habitats, dung beetle communities are characterized by the dominance of a few species, with small-bodied species tending to aggregate more than largebodied species, possibly as a result of having smaller niche differences (Koller et al. 1999; Scheffler 2005; Nichols et al. 2007; Simmons and Ridsdill-Smith 2011). The loss of large-bodied beetles may have significant secondary consequences for community structure and subsequent patterns of ecological function; for example, in the function of waste removal, large-bodied beetles remove disproportionately more dung than smaller-bodied beetles (Larsen and Forsyth 2005; Slade et al. 2007; Dangles et al. 2012). In this study, the small-bodied Trichillum externumpunctatum was an abundant species in the pasture and sugarcane matrices. This species is generally found in pastures in Brazil (Flechtmann et al. 1995; Koller et al. 1999; Aidar et al. 2000), and its high abundance in environments with elevated temperatures, such as pastures and sugarcane plantations, may be an outcome of a nidification behavior (Alarcón et al. 2009) that differs from other endocoprids (Cambefort and Hanski 1991). In this species, neither brood masses nor balls are prepared by the female, and after the feeding stage, the larva leaves the mass of faeces to pupate in the soil underneath it, thus moving to a more humid environment (De Maria et al. 1999; Alarcón et al. 2009).

The lower abundance and richness of dung beetles in most land uses exposes the severe impact of land-use changes on dung beetles and reflects the contrast between the cerrado and the adjacent matrices. The differences between the physical conditions of adjacent habitats can explain our results. For example, soil humidity and structure play a key role in dung beetle reproduction, as these factors are essential for nest construction (Fincher 1973). 
Moreover, the biodiversity of both adults and larvae of dung beetles depends closely on the presence of mammals, since their faeces and carcasses are used as resources (food and nests) by many species (Hanski and Cambefort 1991a, b). Although some mammals are able to use eucalypt plantations (Lyra-Jorge et al. 2010), this is not likely for highercontrast matrices such as sugarcane. Considering that dung beetle abundance may be an indicator of the abundance of mammals (Andresen and Laurance 2007; Nichols et al. 2009), our results also indicate severe impacts of the eucalypt and sugarcane matrices on mammal abundance (Andresen and Laurance 2007; Nichols et al. 2009).

Regarding dung-manipulation strategies, the higher proportion of paracoprids compared to the other guilds has also been found in others studies in the Neotropics (Louzada and Lopes 1997; Liberal et al. 2011; Silva and Di Mare 2012). The higher abundance of this guild might be an outcome of a low competition rate (Hanski and Cambefort 1991a, b) and changes regarding the usage of both land and faecal resources (Halffter and Edmonds 1982), allowing the occurrence of ecologically similar species and increasing the regional diversity of paracoprids (Louzada and Lopes 1997). Paracoprids were most abundant in the pasture matrix; this environment is more advantageous to them than to the other guilds because (1) endocoprids live inside faeces and are more sensitive to high temperatures in pasture, due to the acceleration of faecal drying (Klein 1989); (2) telecoprids roll away large faecal masses in a short time span, and this costs more energy per time than tunneling behavior (Krell et al. 2003). In pasture and sugarcane matrices, the abundance of endocoprids was mainly due to Trichillum externumpunctatum, which has a different nidification behavior (Alarcón et al. 2009) than other endocoprids (Cambefort and Hanski 1991), allowing the larvae and pupae to develop in a consistently moist environment (De Maria et al. 1999; Alarcón et al. 2009).

In landscapes where eucalypt was present, the abundance of all functional guilds was higher in the cerrado than in the matrix, whereas the patterns observed for other land uses differed depending on the guild. It is known that the presence of all guilds in an environment maximizes ecosystem functions (Slade et al. 2007), as the presence of paracoprid and telecoprid species increases seed dispersal, edaphic aeration, and the incorporation of organic matter in the soil. Furthermore, the combined effect of the endocoprids and paracoprids results in a synergistic pattern that facilitates faecal transference to the soil and stimulates microbial activity, with important consequences for soil carbon cycling (Menéndez et al. 2016). Thus, it appears that the services provided by dung beetles are most impaired in eucalypt land uses. Although eucalypt plantations are structurally similar to cerrado fragments and may have a high rate of natural regeneration (Dodonov et al.
2014), this land use largely consists of managed monocultures subject to the application of fertilizers and pesticides and periodic clear-cutting (FAO 2006). These features, as well as the high water demand and the release of allelopathic substances that are characteristic of this tree, have a severe impact on soil structure, which reduces the resilience and biodiversity of dung beetle communities (Lugo 1997).

The NMDS ordination showed that edge communities in eucalypt landscapes had an intermediate composition between those in the cerrado and the adjacent matrix. Thus, while the eucalypt landscapes exhibit decreased abundance of all guilds, the species composition across the edge appears to change smoothly rather than abruptly. Such a pattern reveals that the system that causes less drastic changes in vegetation structure and remains part of the forest cover may offer conditions more favorable to dung beetles in communities located near to the native habitat microclimate (Halffter and Matthews 1996; Halffter and Arellano 2002). The matrix may not be devoid of resources, and different edge-related patterns may be evident depending on whether the resources present in the matrix supplement or complement those found in the cerrado. Supplementary resources provide additional material to that present within the cerrado, whereas complementary resources are essential for the species/species group in question, but are unavailable in the cerrado. (Ries et al. 2004). The eucalypt matrix probably contains the same type of resources as the cerrado, and therefore, species composition at their interface is not likely to vary much, though abundance may change. Conversely, species composition may vary substantially when the resources present in the matrix differ from those in the cerrado. This may be particularly evident with structurally different habitats such as pastures and cerrado.

Our expectations regarding edge influence were only partially corroborated. The gradient model, indicating edge influence, was selected for abundance only in the pasture landscape. This outcome indicates that the variation in abundance is more gradual in this landscape despite the disruption of species composition between the pasture and the cerrado, and despite the negative influence of pasture on dung beetle abundance in communities located near the edge. This may reflect not only a negative effect of the pasture on the adjacent cerrado-resulting, for example, from an altered microclimate (Dodonov et al. 2013) - but also an effect of the cerrado on the pasture matrix, whereby the cerrado edge creates more favorable conditions in the matrix. This latter phenomenon has sometimes been called the 'forest effect' and has been observed, for example, in areas disturbed by insect outbreaks (Franklin et al. 2015) and in agricultural areas adjacent to forest fragments (González et al. 2015). The forest effect may affect factors as diverse as vegetation 
composition (Bueno and Lambí 2015), microclimate (Baker et al. 2014) and predatory insects (González et al. 2015), which can provide resources for mammals in affected areas, consequently affording resources for dung beetles.

Unlike the patterns observed for dung beetle abundance, an edge influence on species richness was never evident for any landscape, whether for the beetles as a whole or for the different guilds. A possible explanation for this can be that with the sampling effort varying according to habitat, the cumulative function of the number of species may have underestimated the richness in cerrado and overestimated it in the disturbed habitat, which may highlight the differences between adjacent environments and hiding gradient patterns. However a weak or non-significant edge influence on dung beetle diversity is commonly observed, even in studies with different sampling design (Durães et al. 2005; Feer 2008; Campbell et al. 2011), and species richness also seems to be scarcely affected by edges in the cerrado. This pattern may be partially due to the patchy and ephemeral nature of their resources (manure and carcasses), making these insects mobile and efficient in tracking those resources throughout the landscape (Roslin 2000). In addition, similar to other savannas, the cerrado is a naturally patchy environment with alternating patches of greater or smaller woody plant cover (Wiegand et al. 2006; Gonçalves and Batalha 2011). Furthermore, small-sized cerrado mammals may not be affected by edges at the scale of this study (Di Napoli and Caceres 2012). Thus, the distribution of dung beetles in our study fragments may be sufficiently heterogeneous to preclude the detection of edge influence on the number of species (Harper et al. 2005).

Besides the fact that most of dung beetles in tropical savannas are not host specialists (Spector and Ayzama 2003), the differences in mammal communities between the different land uses (Lyra-Jorge et al. 2010; Martin et al. 2012) as well as the presence of the dung of generalist and edge-preferring mammals at the edge may aid in explaining our results. It must also be considered that dung beetles may use all of the studied matrices to some degree, albeit often with lower abundance, as shown by the results above. An edge influence on species richness could be more evident if we were to consider more inhospitable matrices such as urban areas or highways (Noreika and Kotze 2012). Still, a lack of relationship between edge contrast and edge influence has been observed for other variables in the cerrado, including vegetation height, canopy closure and plant litter biomass (Dodonov et al. 2013, 2016). The great diversity of this group of beetles results in a myriad of environmental and resource preferences as well as differences in movement capabilities among species, leading to a variation in edge-related patterns among the species such that the loss of some species at the edges is compensated by other species (Barbero et al. 1999; Peyras et al. 2013; Figueiras et al. 2015).

Finally, landscape features also play a key role in the detection of the edge influence on organisms, especially in highly fragmented and heterogeneous landscapes (Ries et al. 2004). One of the best-known landscape metrics to have an impact on edge influence is habitat area, since small patches have higher densities of edge area (Fletcher et al. 2007; Banks-Leite et al. 2010). As dung beetles are sensitive to patch size (Feer and Hingrat 2005; Horgan 2007), area and edge effects interact synergistically in such a way that small patches may be unable to sustain species that avoid edges; hence a misdetection of the edge influence (Ewers et al. 2007). Thus, the inclusion of larger fragments could have aided in the detection of edge influence on species richness. However, considering that small remnants dominate highly fragmented regions such as Southeast Brazil, our results are representative of the patterns that may be observed in this region.

In conclusion, we showed clear effects of different land uses on the abundance, richness and composition of dung beetles as a whole and of the different dung-manipulation strategies in an agricultural landscape containing cerrado fragments. We also demonstrated the occurrence of edge influence on the abundance of this group, albeit only in the pasture matrix. Although edge influence was not often observed for species richness, there were great differences between the vegetation remnants and the adjacent land uses for both richness and abundance. Thus, anthropogenic land uses, including low-contrast ones such as eucalypt plantations, tend to decrease the abundance and richness of dung beetles, with possible consequences for several ecological processes including decomposition and nutrient cycling. These effects may extend into the cerrado remnants, decreasing their core area, the impacts being especially severe considering the high degree of fragmentation of this vegetation.

Acknowledgments We thank Mateus Fernando de Souza for aid in several phases of the research, especially on species identification; Sean Miki Hieda and Carlos Fonseca for field work support; Prof. Fernando Vaz-de-Melo for aid in species identification, and Megan King for proofreading the manuscript. We also thank the São Paulo Research Foundation (FAPESP) for funding this research via a grant to FA, as well as the National Council for Scientific and Technological Development (CNPq) and the Coordination for the Improvement of Higher Education Personnel (CAPES) for support granted to FM and PD. MCR receives research grant from CNPq (process 312045/20131 ) and is continually supported by FAPESP (process 2013/50421-2).

\section{References}

Aidar T, Koller WW, Rodrigues SR, Corrêa AM, Silva JCC, Balta OS, Oliveira JM, Oliveira VL (2000) Besouros coprófagos 
(Coleoptera: Scarabaeidae) coletados em Aquidauana, MS, Brasil. An Soc EntomolBras 29:817-820

Alarcón DL, Halffter G, Vaz-de Mello FZ (2009) Nesting behavior in Trichilum Harold, 1868 and related genera (Coleoptera: Scarabaeidae: Scarabaeinae: Ateuchini: Scarimina): a primitive process or a loss of nidification? Coleopts Bull 63:289-297

Almeida S, Louzada J, Sperber C, Barlow J (2011) Subtle land-use change and tropical biodiversity: dung beetle communities in cerrado grasslands and exotic pastures. Biotropica 43:704-710

Andresen E, Laurance SGW (2007) Possible indirect effects of mammal hunting on dung beetle assemblages in Panama. Biotropica 39:141-146

Audino LD, Louzada J, Comita L (2014) Dung beetles as indicators of tropical forest restoration success: Is it possible to recover species and functional diversity? Biol Conserv 169:248-257

Baker TP, Jordan GJ, Steel EA, Fountain-Jones NM, Wardlaw TJ, Baker SC (2014) Microclimate through space and time: microclimatic variation at the edge of regeneration forests over daily, yearly and decadal time scales. Forest Ecol Manag 334:174-184

Banks-Leite C, Ewers RM, Metzger J (2010) Edge effects as the principal cause of area effects on birds in fragmented secondary forest. Oikos 119:918-926

Barbero E, Palestrini C, Rolando A (1999) Dung beetle conservation: effects of habitat and resource selection (Coleoptera: Scarabaeoidea). J Insect Conserv 3:75-84

Barragán F, Moreno CE, Escobar F, Halffter G, Navarrete D (2011) Negative impacts of human land use on dung beetle functional diversity. PloS One 6:17976

Barrera CA, Buffa LM, Valladares G (2015) Do leaf-cutting ants benefit from forest fragmentation? Insights from community and species-specific responses in a fragmented dry forest. Insect Conserv Divers 8:456-463

Barton K (2015) MuMIn: Multi-model inference. R package version 1.15.1. https://CRAN.R-project.org/package $=$ MuMIn

Bates D, Maechler M, Bolker B, Walker S (2015) Fitting linear mixed-effects models using lme4. J Stat Softw 67:1-48

Beiroz, WIS (2012) Resposta da diversidade funcional de Scarabaeinae (Coleoptera: Scarabaeidae) aos diferentes usos de solo na Amazônia. Dissertation, Universidade Federal de Lavras

Borges PAV, Brown VK (2001) Phytophagous insects and web-building spiders in relation to pasture vegetation complexity. Ecography 24:68-82

Brussaard L, Behan-Pelletier M, Bignel IDE, Brown VK, Didden W, Folgarait P, Fragoso C, Freckman DW, Vadakattu VSR, Hattori T, Hawksworth DV, Klopatek C, Lavelle P, Malloch DW, Rusek J, Söderström B, Tiedje JM, Virginia RA (1997) Biodiversity and ecosystem functioning in soil. Ambio 26:563-570

Bueno A, Llambí LD (2015) Facilitation and edge effects influence vegetation regeneration in old-fields at the tropical Andean forest line. Appl Veg Sci 18:613-623

Burnham SK, Anderson DR (2002) Model selection and multimodel inference: a pratical information-theoretic approach, 2 edn. Springer, New York

Burnham KP, Anderson DR (2014) $P$ values are only an index to evidence: 20th- vs. 21st-century statistical science. Ecology 95:627-630

Butchart SHM et al (2010) Global biodiversity: indicators of recent declines. Science 328(5982):1164-1168

Butchart, SHM, Walpole M, Collen b, Strien A, Scharlemann JPW, Almond, REA, Baillie JEM, Bomhard B, Brown C, Bruno J, Carpenter KE, Carr GM, Chanson J, Chenery AM, Csirke J, Davidson NC Dentener F, Foster M, Galli A, Galloway JN, Genovesi P,. Gregory RD, Hockings M, Kapos V, Lamarque JF, Leverington F, Loh J, McGeoch MA, McRae L, Minasyan A, Morcillo MH, Oldfield TEE, Pauly D, Quader S, Revenga C, Sauer JR, Skolnik B, Spear D, Stanwell-Smith D, Stuart SN,
Symes A, Tierney M, Tyrrell TD, Vié JC, Watson R (2010) Global biodiversity: indicators of recent declines. Science 328(5982):1164-1168

Cambefort Y, Hanski I (1991) Dung beetle population biology. In: Hanski I, Cambefort Y (eds) Dung beetle ecology. Priceton Univerity Press, Princeton, pp 36-50

Campbell RE, Harding JS, Ewers RM, Thorpe S, Didham RK (2011) Production land use alters edge response functions in remnant forest invertebrate communities. Ecol Appl 21(8):3147-3161

Campos RC, Hernández MIM (2013) Dung beetle assemblages (Coleoptera, Scarabaeinae) in Atlantic forest fragments in southern Brazil. Rev Bras Entomol 57:47-54

Cooney SA, Schauber EM, Hellgren EC (2015) Comparing permeability of matrix cover types for the marsh rice rat (Oryzomys palustris). Landscape Ecol 30:1307-1320

Coutinho LM (1978) O conceito de cerrado. Rev Bras Bot 1:17-23

Dangles O, Carpio C, Woodward G (2012) Size-dependent species removal impairs ecosystem functioning in a large-scale tropical field experiment. Ecology. doi:10.1890/12-0510.1

De Maria IC, Castro OM, Souza Dias H (1999) Atributos físicos do solo e crescimento radicular de soja em latossolo roxo sob diferentes métodos de preparo do solo. R Bras Ci solo 23:703-709

Delgado JN, Arroyo NL, Arevalo JR, Fernandez-Palacios JM (2007) Edge effects of roads on temperature, light, canopy closure, and canopy height in laurel and pine forests (Tenerife, Canary Islands). Landsc Urban Plan 81:328-340

Delgado JD, Arroyo NL, Arévalo JR, Fernández-Palacios JM (2013a) Road edge effects on litter invertebrate communities of subtropical forests. J Natl Hist 47:203-236

Delgado JD, Arroyo NL, Arévalo JR, Fernández-Palacios JM (2013b) The responses of leaf litter invertebrates to environmental gradients along road edges in subtropical island forests. Pedobiology $56: 137-146$

Dennis, RL, Shreeve TG, Van Dyck H. (2006). Habitats and resources: the need for a resource-based definition to conserve butterflies. Biodiv Conserv 15(6):1943-1966

Di Napoli RP, Caceres NC (2012) Absence of edge effects on small mammals in woodland-savannah remnants in Brazil. Commun Ecol 13:11-20

Dodonov P, Harper KA, Silva-Matos DM (2013) The role of edge contrast and forest structure in edge influence: vegetation and microclimate at edges $\mathrm{n}$ the Brazilian cerrado. Plant Ecol 214:1345-1359

Dodonov P, da Silva DM, Rosatti NB (2014) Understorey vegetation gradient in a Eucalyptus grandis plantation between a savanna and a semideciduous forest. N Z J For Sci 44(1)

Dodonov P, Braga AL, Harper KA, Silva-Matos DM (2016) Edge influence on plant litter biomass in forest and savanna in the Brazilian cerrado. Austral Ecol. (In press)

Doube BM (1990) A functional classification for analysis of the structure of dung beetle assemblages. Ecol Entomol 15:371-383

Driscoll DA, Banks SC, Barton PS, Lindenmayer DB, Smith AL (2013) Conceptual domain of the matrix in fragmented landscapes. Trends Ecol Evol 28:605-613

Durães R, Martins WP, Vaz-de-Mellos FZ (2005) Dung beetle (Coleoptera: Scarabaeidae) assemblages across a natural forest-cerrado ecotone in Minas Gerais, Brazil. Neotrop Entomol 34:721-731

Ewers RM, Thorpe S, Didham RK (2007) Synergistic interactions between edge and area effects in a heavily fragmented landscape. Ecology 88:96-106

Fahrig L (2003) Effects of habitat fragmentation on biodiversity. Annu Rev Ecol Evol Syst. doi:10.1146/annurev. ecolsys.34.011802.132419

FAO (2006) Global forest resources assessment 2005: progress towards sustainable forest management. Forestry Paper 147. 
(accessed S). United Nations Food and Agriculture Organization. (FAO, Rome. Available from: http://www.fao.org

Feer F (2008) Responses of dung beetle assemblages to characteristics of rain forest edges. Ecotropica 14:49-62

Feer F, Hingrat Y (2005) Effects of forest fragmentation on a dung beetle community in French Guiana. Conserv Biol 19:1103-1112

Figueiras BK, Tabarelli M, Leal IR, Vaz-de-Mello FZ, Iannuzzi L (2015) Dung beetle persistence in human-modified landscapes: Combining indicator species with anthropogenic land use and fragmentation-related effects. Ecol Indic 55:65-73

Fincher GT (1973) Dung beetles as biological control agents for gastrointestinal parasites of livestock. J Parasitol 59:396-399

Flechtmann CAH, Rodrigues SR, Couto HTZ (1995) Controle biológico da mosca-dos-chifres (Haematobia irritans irritans) em Selvíria, Mato Grosso do Sul. Comparação entre métodos de coleta de besouros coprófagos (Scarabaeidae). Rev Bras Entomol 39:259-276

Fletcher RJ Jr, Ries L, Battin J, Chalfoun AD (2007) The role of habitat area and edge in fragmented landscapes: definitively distinct or inevitably intertwined? Can J Zool 85:1017-1030

Foggo A, Ozanne CMP, Speigh, TMR, Hambler C (2001) Edge effects and tropical forest canopy invertebrates. Plant Ecol 153:347-359

Franklin CMA, Harper KA, Murphy LK (2015) Structural dynamics at boreal forest edges created by a spruce budworm outbreak. Silva Fennica 49, article 1267.

Gardner TA, Barlow J, Sodhi NS, Peres CA (2010) A multi-region assessment of tropical forest biodiversity in a human-modified world. Biol Conserv 143(10):2293-2300

Gittings T, Giller PS (1998) Resource quality and the colonization and sucession of coprophagous dung beetles. Ecography 21:581-592

Gonçalves CS, Batalha MA (2011) Towards testing the "honeycomb rippling model" in cerrado. Braz J Biol 71:1-8

González E, Salvo A, Valladares G (2015) Sharing enemies: evidence of forest contribution to natural enemy communities in crops, at different spatial scales. Insect Conserv Diver 8:359-366

Gordon RD, Cartwright OL (1974) Survey of food preferences of some North American Canthonini (Coleoptera: Scarabaeidae). Entomol News 85:181-185

Haddad NM, Brudvig LA, Clobert J, Davies KF, Gonzalez A, Holt RD, Lovejoy TE, Sexton JO, Austin MP, Collins CD, Cook WM, Damschen EI, Ewers RM, Foster BL, Jenkins CN, King AJ, Laurance WF, Levey DJ, Margules CR, Melbourne BA, Nicholls AO, Orrock JL, Song DX, Townnshend JR (2015) Habitat fragmentation and its lasting impact on Earth's ecosystems. Sci Adv 1:e500052

Halffter G, Aurellano L (2002) Response of dung beetle diversity to human-induced changes in a tropical landscape. Biotropica 34:144-154

Halffter G, Edmonds WD (1982) The nesting behavior of dung beetles (Scarabaeinae): an ecological and evolutive approach. Unesco, Instituto Ecologia, México

Halffter G, Mathews EG (1996) The natural history of dung beetles of the subfamily Scarabaeinae (Coleoptera, Scarabaeidae). Folia Entomol Mex 12:1-312

Hansbauer MM, Storch I, Knauer F, Pilz S, Küchenhoff H, Végvári Z, Pimentel RG, Metzger JP (2009) Landscape perception by forest understory birds in the Atlantic Rainforest: black-and-white versus shades of grey. Land Ecol 25:407-417

Hanski I, Cambefort Y (1991a) Competition in dung beetle. In: Hanski I, Cambefort Y (eds) Dung beetle ecology. Princeton University, New Jersey, pp 305-329

Hanski I, Cambefort Y (1991b) Dung beetle ecology. Princeton University Press, New Jersey
Harper KA, Macdonald SE, Burton PJ, Chen J, Brosofske KD, Saunders SC, Euskirchen ES, Roberts D, Jaiteh MS, Esseen PA (2005) Edge influence on forest structure and composition in fragmented landscapes. Conserv Biol 19:768-782

Hernández MIM, Vaz-De-Mello FZ (2009) Seasonal and spatial species richness variation of dung beetle (Coleoptera, Scarabaeidae s. str.) in the Atlantic Forest of southeastern Brazil. Rev Bras Entomol 53:607-613

Horgan FG (2007) Dung beetles in pasture landscapes of Central America: proliferation of synanthropogenic species and decline of forest specialists. Biodivers Conserv 16:2149-2165

Klein BC (1989) Effects of forest fragmentation on dung and carrion beetle communities in Central Amazonia. Ecology 70:1715-1725

Koller WW, Gomes A, Rodrigues SR, Alves RGO (1999) Besouros coprófagos (Coleoptera: Scarabaedae) coletados em Campo Grande. An Soc Entomol Bras 28:403-412

Kowal VA, Cartar RV (2012) Edge effects of three anthropogenic disturbances on spider communities in Alberta's boreal forest. J Insect Conserv 16:613-627

Krell FT, Krell-Westerwalbesloh S, Weiß I, Eggleton P, Linsenmair KE (2003) Spatial separation of Afrotropical dung beetle guilds: a trade-off between competitive superiority and energetic constraints (Coleoptera: Scarabaeidae). Ecography 26:210-222

Larsen T, Forsyth A (2005) Trap spacing and transect design for dung beetle biodiversity studies. Biotropica 37:322-325

Laurance WF, Lovejoy TE, Vasconcelos HL, Bruna EM, Didham RK, Stouffer PC, Gascon C, Bierregaard RO, Laurance SG, Sampaio E (2002) Ecosystem decay of Amazonian forest fragments: a 22-year investigation. Conserv Biol 16:605-618

Liberal CN, Isidro de Farias ÃM, Meiado MV, Filgueiras BKC, Iannuzzi L (2011) How habitat change and rainfall affect dung beetle diversity in Caatinga, a Brazilian semi-arid ecosystem. J Insect Sci 11:114

Louzada JNC, Lopes FSA (1997) Comunidade de Scarabaeidae copro-necrófago (Coleoptera) de um fragmento de Mata Atlântica. Rev Bras Entomol 41:117-121

Louzada JNC, Silva PRC (2009) Utilization of introduced Brazilian pastures ecosystems by native dung beetles: Diversity patterns and resource use. J Insect Conserv 2:45-52

Lugo AE (1997) The apparent paradox of reestablishing species richness on degraded lands with tree monocultures. Forest Ecol Manag 99(1-2):9-19

Lyra-Jorge MC, Ribeiro MC, Ciocheti G, Tambosi LR, Pivello VR (2010) Influence of multi-scale landscape structure on the occurrence of carnivorous mammals in a human-modified savanna, Brazil. Eur J Wildl Res 56:359-368

Martin PS, Gheler-Costa C, Lopes PC, Rosalino LM, Verdade LM (2012) Terrestrial non-volant small mammals in agro-silvicultural landscapes of Southeastern Brazil. Forest Ecol Manag 282:185-195

Menéndez R, Webb P, Orwin KH (2016) Complementarity of dung beetle species with different functional behaviours influence dung e soil carbon cycling. Soil Biol Biochem 92:142-148

Meyer ST, Leal IR, Wirth R (2009) Persisting hyper-abundance of leaf-cutting ants (Atta spp.) at the edge of an Atlantic Forest fragment. Biotropica 41:711-716

Murtaugh PA (2014) In defense of $P$ values. Ecology 95:611-617

Nichols E, Larsen T, Spector S, Davis AL, Escobar F, Favila M, Network TSR (2007) Global dung beetle response to tropical forest modification and fragmentation: a quantitative literature review and meta-analysis. Biol Conserv 137:1-19

Nichols E, Spector S, Louzada J, Larsen T, Amezquita S, Favila ME, Network TSR (2008) Ecological functions and ecosystem services provided by Scarabaeinae dung beetles. Biol Conserv 141:1461-1474 
Nichols E, Gardner T.A, Peres CA, Spector S, The Sarabaeinae Research Network (2009) Co-declining mammals and dung beetles: an impending ecological cascade. Oikos 118: 481-487

Noreika N, Kotze DJ (2012) Forest edge contrasts have a predictable effect on spatial distribution of carabid beetles in urban forests. J Insect Conserv 16:867-881

Oksanen J, Blanchet FG, Kindt R, Legendre P, Minchin PR, O'Hara RB, Oksanen MJ (2013) Package 'vegan'. Community ecology package, version, 2 (9)

Peck SB, Howden HF (1984) Response of a dung beetle guild to different sizes of dung bait in a Panamanian rainforest. Biotropica $16: 235-238$

Peyras M, Vespa NI, Bellocq MI, Zurita GA (2013) Quantifying edge effects: the role of habitat contrast and species specialization. J Insect Conserv 17:807-820

Pohlman CL, Turton SM, Goosem M (2007) Edge effects of linear canopy openings on tropical rain forest understory microclimate. Biotropica 39:62-71

R Core Team (2015) R: A language and environment for statistical computing. R Foundation for Statistical Computing, Vienna, Austria, 2013. Document freely available on the internet at: http://www.r-project.org

Ribeiro JF, Walter BMT (2008) As principais fisionomias do bioma Cerrado. In: Sano SM, Almeida SP, Ribeiro JF (eds) Cerrado: ecologia e flora. Embrapa Informação Tecnológicas, Brasília

Ribeiro MC, Metzger JP, Martensen AC, Ponzoni FJ, Hirota MM (2009) The Brazilian Atlantic Forest: How much is left, and how is the remaining forest distributed? Implications for conservation. Biol Conserv 142:1141-1153

Ries L, Fletcher Jr RJ, Battin J, Sisk TD (2004) Ecological responses to habitat edges: mechanisms, models, and variability explained. Annu Rev Ecol Evol Syst 35:491-522

Roslin T (2000) Dung beetle movements at two spatial scales. Oikos 91:323-335

Roslin T, Viljanen H (2011) Dung beetle populations: structure and consequences. In: Simmons LW, Ridsdill-Smith TJ (eds) Ecology and evolution of dung beetle. Blackwell, Oxford, p 18

Scheffler P (2005) Dung beetle (Coleoptera: Scarabaeinae) diversity and community structure across three disturbance regimes in eastern Amazonia. J Trop Ecol 21:9-19

Silva PG, Di Mare R (2012) Escarabeíneos copro-necrófagos (Coleoptera, Scarabaeidae, Scarabaeinae) de fragmentos de Mata Atlântica em Silveira Martins, Rio Grande do Sul, Brasil. Iheringia, Série Zoologia 102:197-205

Silva PG, Hernández MIM (2015) Spatial patterns of movement of Dung beetle species in a Tropical Forest suggest a new trap spacing for Dung beetle biodiversity studies. PLoS One 10:e126112

Simmons LW, Ridsdill-Smith TJ (2011) Reproductive competition and its impact on the evolution and ecology of dung beetles. In: Simmons LW, Ridsdill-Smith TJ (eds) Ecology and evolution of dung beetle. Blackwell, Oxford, p 18

Slade EM, Mann DJ, Villanueva JF, Lewis OT (2007) Experimental evidence for the effects of dung beetle functional group richness and composition on ecosystem function in a tropical forest. $\mathrm{J}$ Anim Ecol 76:1094-1104

Sparovek G, Barretto A, Klug I, Papp L, Lino J. (2011). A revisão do Código Florestal brasileiro. Novos Estudos CEBRAP 89:111-135

Spector S, Ayzama S (2003) Rapid turnover and edge effects in Dung beetle assemblages (Scarabaeidae) at a Bolivian Neotropical Forest - Savanna Ecotone1. Biotropica 35:394-404

Valente RO (2001) Análise da estrutura da paisagem na bacia do rio Corumbataí. M. Sc. Thesis,-Escola Superior de Agricultura "Luiz de Queiroz". Universidade de São Paulo, Piracicaba

Valpine $\mathrm{P}$ (2014) The common sense of $P$ values. Ecology 95:617-621

Verdú JR, Galante E (2004) Behavioral and morphological adaptations for a low-quality resource in semi-arid environments: dung beetles (Coleoptera, Scarabaeoidea) associated with the European rabbit (Oryctolagu cuniculus L.). J Nat Hist 38:705-715

Vulinec K (2002) Dung beetle communities and seed dispersal in primary forest and disturbed land in Amazonia. Biotropica 34:297-309

Whitford WG (1996) The importance of the biodiversity of soil biota in arid ecosystems. Bio Conserv 5:185-195

Wiegand K, Saltz D, Ward D (2006) A patch-dynamics approach to savanna dynamics and woody plant encroachment 0 Insights from an arid savanna. Perspect Plant Ecol Evol Syst 7:229-242

Wood SN (2011) Fast stable restricted maximum likelihood and marginal likelihood estimation of semiparametric generalized linear models. J R Stat Soc 73:3-36

Wood SN, Sheipl F (2014) gamm4: Generalized additive mixed models using mgcv and lme4. R package version $0.2-3$. https:// CRAN.R-project.org/package $=$ gamm 4

Zavatini JÁ, Cano H (1993) Variações do ritmo pluvial na bacia do rio Corumbataí-SP. Boletim de Geografia Teorética 23:215-240

Zuur A, Ieno EN, Walker N, Saveliev AA, Smith GM (2009) Mixed effects models and extensions in ecology with R. Springer Science \& Business Media 